\title{
Nutrient Recovery from Cyanobacteria Biomasses Using Purple Nonsulfur Bacterium Rhodopseudomonas palustris
}

\author{
Yingying Tian ${ }^{1,2}$, Xingqiang Wu ${ }^{1 *}$, Bing Feng ${ }^{1,2}$, Cuicui Tian ${ }^{1}$, \\ Chunbo Wang ${ }^{1}$, Bangding Xiao ${ }^{1 *}$ \\ ${ }^{1}$ Key Laboratory of Algal Biology of Chinese Academy of Sciences, Institute of Hydrobiology, \\ Chinese Academy of Sciences, Wuhan 430072, China \\ ${ }^{2}$ University of Chinese Academy of Sciences, Beijing 100101, China
}

Received: 6 March 2017

Accepted: 11 April 2017

\begin{abstract}
Occurrences of harmful cyanobacterial blooms are a worldwide environmental problem in most eutrophic lake ecosystems. But what should be noticed is that cyanobacteria can be used as a useful resource due to the wide range of metabolites they produce. Nutrient partitioning using purple nonsulfur bacteria (PNSB) has the potential to biologically concentrate nutrients. The present study evaluated the kinetics of nutrients released from decomposed field blue green algae (BGA) biomasses. The potential of nutrient acquisition from decomposed BGA biomasses for culturing Rhodopseudomonas palustris (R. palustris) was investigated via fed-batch experiments. Results indicated that $R$. palustris stimulated in algae substrates with algae biomasses ranging from 3.33 to $10 \mathrm{~g} / \mathrm{L}$. Removal efficiencies of $\mathrm{N}$ and $\mathrm{P}$ in the stationary phase of growth were at least $40 \%$ and $95 \%$, respectively, of all the nitrogen $(\mathrm{N})$ and phosphorus $(\mathrm{P})$ released. Additionally, the cellular contents like total lipid and poly- $\beta$-hydroxybutyrate (PHB), as well as the fatty acids produced by R. palustris, were consistent. Hence, practice based on the bacterial production for the nutrient recovery from BGA biomasses provides a new insight in field algae disposal. It will lower the chances of secondary pollution due to algae decay and produce giant cells of $R$. palustris and surely will prosper the industries applying $R$. palustris.
\end{abstract}

Graphic Abstract

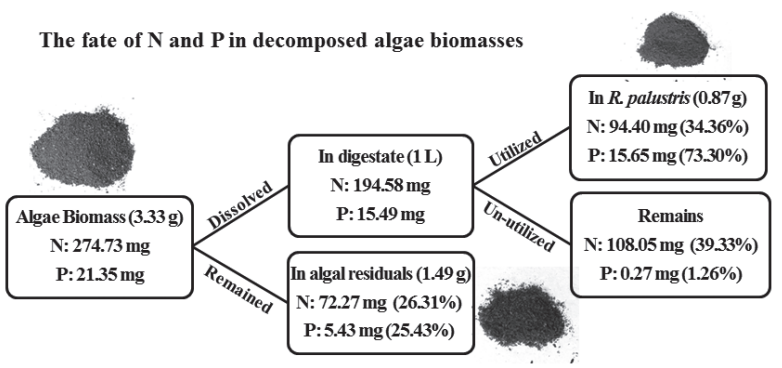

*e-mail: bdxiao@ihb.ac.cn, xqwu@ihb.ac.cn 
Keywords: purple nonsulfur bacteria, Rhodopseudomonas palustris, biomass production, blue green algae, nutrient recovery

\section{Introduction}

Though difficult to verify, it is widely held that harmful algal bloom outbreaks have aggravated over the past few decades at both global and regional scales [1]. Blooms of blue green algae (BGA) are more frequent and widespread, causing global public health and environmental concern. In $2007,40 \%$ of the total area of Lake Taihu was incredibly covered by cyanobacterial blooms challenging more than two million residents with a week-long drinking water crisis [2-3]. Physical and chemical methods can remove algae from water being the algae sludge. Dealing with this algae sludge will be an issue point for preventing secondary pollution from algae decay [4]. Therefore, management of these huge biomasses is an ongoing challenge for lake managers and policymakers.

Algae biomasses take in huge quantities of carbon $(\mathrm{C})$, nitrogen $(\mathrm{N})$, and phosphorus $(\mathrm{P})$ from water bodies. Besides the essential elements of C, N, P, and the minerals of microalgae met the nutrient requirements of the anaerobic microflora [5]. As mentioned, algae are not only the product of eutrophication in natural lakes but also can be used as potent substrate due to the abundant nutrients they release by anaerobic digestion [6].

As numerously reported, purple nonsulfur bacteria (PNSB) are an important subgroup of anoxygenic phototrophs used for waste biodegradation and hydrogen production [7-8]. Rhodopseudomonas palustris (R. palustris) is among the most metabolically versatile microorganisms known and reserves a much larger inventory of degradation genes than current knowledge by genome sequencing [9]. Phototrophic bacteria are apt to store organic carbon as poly-hydroxybutyrate (PHB) [10] and help with nutrient removal, e.g., by inorganic poly-phosphate formation [11]. Additionally, $R$. palustris TN110 showed great potential as a biofertilizer in that it provides ammonia and plant growth-promoting substances (of indole-3-acetic acid and 5-aminolevulinic acid), and reduces heavy metals and methane greenhouse gasses [12]. Though PNSB have significant potential in bioremediation, few researchers have focused on the selection of a natural feedstock for $R$. palustris biomass production.

On most occasions, raw substrates used for sustaining PNSB are wastewaters having combined effects of waste removal and energy production (i.e., hydrogen) [13]. The common characteristic of the wastewater steams is the abundance of bioavailable organic materials (lipids, carbohydrates, proteins). These substances are also important compositions in the algae cell [14], which are a potential nutrient source [6]. It was reported that microalgal biomasses or extracts coupled with anaerobic bacteria (e.g., Lactobacillus amylovorus or Clostridium butyricum) sustained Rhodobium marinum strain A-501 [15] and Rhodobacter sphaeroides strain KD131 [16].
However, the strains of algae utilized are exclusively green algae either from freshwater species of Chlamydomonas reinhardtii and Chlorella vulgaris or the marine species of Dunaliella tertiolecta [15-17]. Few researchers have investigated the potential of field BGA as substitutive substrate for $R$. palustris. On the contrary, it is more meaningful using field BGA as eco-feedstock to the mass production of $R$. palustris.

It is urgent to deal with the increasing amount of BGA biomass for water quality improvement and secondary pollution prevention. PNSBs are known as fast-growing microorganisms that can be used as an alternative mediator for combined biological carbon, nitrogen, and phosphorous removal [18]. In the present study, three aspects on the feasibility of nutrient recovery form decomposed algae using $R$. palustris are to be involved: 1 ) Kinetics of nutrients released from the decomposed BGA biomasses, 2) Determining the growth performance of $R$. palustris in algae substrates, and 3) Identifying nutrient removal efficiency and quantify the cellular contents of $R$. palustris. In this paper, we present the first description of using field algae as the potent feedstock for $R$. palustris production achieving the goals of nutrient recovery. These results provide new insights into the management of BGA and concomitantly produce $R$. palustris cells that are biological water purifiers.

\section{Material and Methods}

\section{Bacteria}

The pure strain of PNSB was maintained in ATYP liquid medium under weak illumination (1,000 lux) at $28^{\circ} \mathrm{C}$. This strain was isolated in a sediment sample from Lake Donghu (Wuhan, China; for the compositions of ATYP, see [19]). The online blast result discriminates the isolate to species of Rhodopseudomonas palustris under accession number KU886140 and it was designated $R$. palustris strain PUF1. Similar sequences of its relatives were downloaded from the database of Genbank (ncbi. nlm.nih.gov/nucleotide) for a phylogenetic analysis shown in Fig. 1. The phylogenetic tree was constructed with MEGA 5.1 software by the neighbor-joining method and the topology of the tree was evaluated using a bootstrap with 1,000 replications.

\section{Field Algae Collection}

Fresh BGA were collected in August 2015 at the downwind area in Lake Dianchi (Kunming, China). The harvested fresh algae were concentrated to form algae sludge ( $\sim 5 \%$ total solids). Next, smooth the thickened BGA biomasses onto the nonwoven cloth to dry in shade. After drying, the algae biomasses have a moisture 


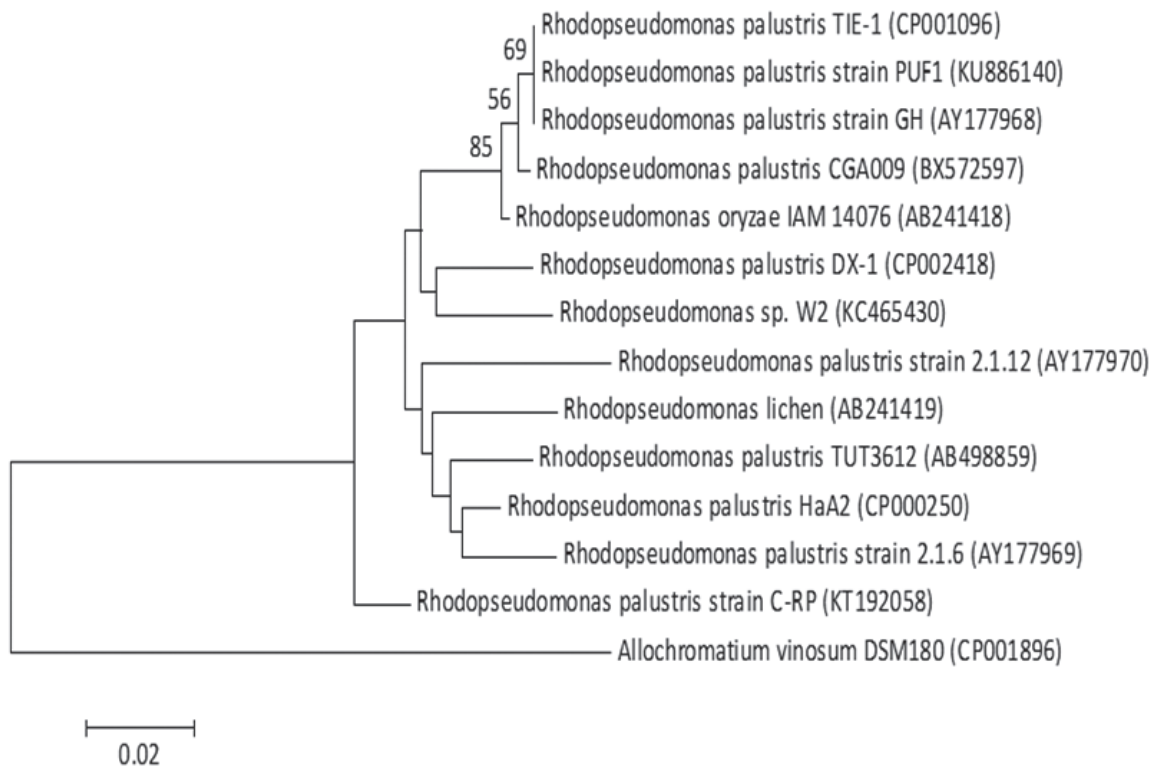

Fig. 1. A phylogenetic tree based on puf M sequences of R. palustris strain PUF1 and other closely related species. The numbers at the nodes represent the level of bootstrap support (\%) based on the neighbor-joining analyses of 1,000 resampled datasets. The scale bar represents the branch length.

content of approximately $10 \%$. Finally, they were ground mechanically into small granules within $0.43 \mathrm{~mm}$ forming the homogenous feedstock.

\section{Experimental Design}

\section{Kinetics of Nutrients Released from Decomposed $B G A$ Biomasses}

In this section, experiments were performed for kinetics determination on nutrient releasing derived from the decomposed algae biomasses. Suspend the pre-weighed algae biomasses with aseptic double-distilled water to a final algal concentration of $5,10,15$, and $20 \mathrm{~g} / \mathrm{L}$. Total dissolved nitrogen (TDN) and total dissolved phosphorus (TDP) in the liquid were periodically examined.

\section{Growth Performance of $R$. palustris at Different Algae Substrates}

In this study, serum bottles (diameter $6.5 \mathrm{~cm}$, height $14 \mathrm{~cm}$ ) with a working volume of $300 \mathrm{~mL}$ were used as the photo-bioreactors. $R$. palustris stain PUF1 was used as the initial inoculant after having it rinsed three times to remove the ATYP medium. Before experiments, certain amounts of BGA together with the bioreactors were sterilized at $121^{\circ} \mathrm{C}$ for $30 \mathrm{~min}$. After cooling to room temperature, approximately $300 \mathrm{~mL}$ aseptic distilled water was added to the bioreactors followed by R. palustris inoculation. An initial cell concentration of $\sim 0.04$ (OD ${ }_{650 \mathrm{~mm}}$, optical density at $650 \mathrm{~nm}$ ) was recommended and the experimental sets were incubated at $28^{\circ} \mathrm{C}$ with an observed light intensity of $\sim 2,000$ lux on the surface.

\section{Analytical Methods}

\section{Analysis of Cell Growth}

The bacterial biomass of $R$. palustris was determined by measuring OD650 nm [20]. A logistic (sigmoid) model was adopted to fit the whole growth curve. OD can be described as a function of time using Equation 1:

$$
\mathrm{OD}(\mathrm{t})=a /(1+\exp (-k(\mathrm{x}-x c)))
$$

...where $a$ represents the maximum $\mathrm{OD}\left(\mathrm{OD}_{\max }\right)$ and $k$ indicates the specific growth rate, and $x c$ is the time to half $\mathrm{OD}_{\max }$, which can be normalized to compare growth rates with diverse starting ODs and different start-up rates. The cell cultures $(2 \mathrm{~mL})$ were centrifuged at $10,000 \mathrm{~g}$ for 10 min to obtain the cell pellets. The bacteriochlorophyll a (Bchl a) of R. palustris cells were extracted with acetone and methanol $(7: 2(\mathrm{v} / \mathrm{v}))$. The supernatants from extracts were measured at $775 \mathrm{~nm}$ [21] for the determination of Bchl a concentration.

\section{Total Lipid, PHB, and Fatty Acids Determination}

We examined cells of $R$. palustris in stationary phase growth. The amounts of total lipid and PHB were calculated as contents to the dry cell weights. A certain amount of lyophilized cells (generally $0.20 \mathrm{~g}$ ) were directly extracted with methanol: chloroform $(1: 2, \mathrm{~V}: \mathrm{V})$ for total lipid measurement. The extracts were dried under nitrogen [22]. PHB is a biodegradable material that produces and accumulates in the late exponential and stationary 
phases of PNSB. The extraction of PHB was performed according to a protocol previously described [23]. Thawed cell pellets were used for the profile of cellular fatty acids according to the indicated reference [24].

\section{Water Quality Determination}

Approximately $8 \mathrm{~mL}$ of cell suspension was periodically collected. Supernatant was used for water quality determination according to the standard methods (APHA, 1998) [25]. Parameters of TN (total nitrogen), TDN (total dissolved nitrogen), NH4-N (nitrogen in ammonia), TP (total phosphorus), TDP (total dissolved phosphorus), T-COD (total chemical oxygen demand), and D-COD (dissolved chemical oxygen demand) were determined.

\section{Statistical Analysis}

Three replicates were performed for each experiment. Mean values and the standard deviations were presented.
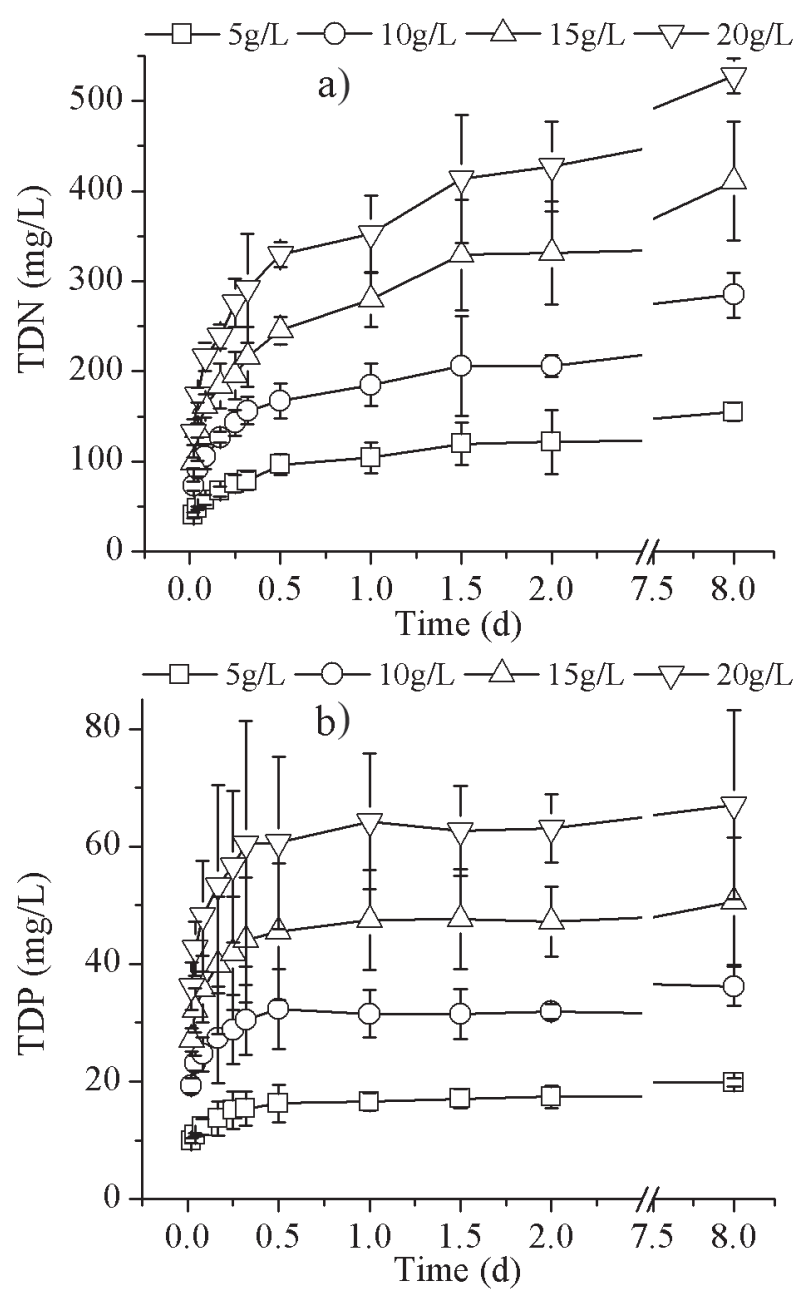

Fig. 2. Kinetics of nutrient releasing from algae biomasses calculated on the concentration of TDN a) and TDP b) in the digestates. Values are means of three replications \pm standard deviation.
Significant differences among means were calculated at a p-value $<0.05$. Student's t-test was used to compare the total lipid and PHB yields from algae substrates and ATYP medium and nutrient removal efficiencies from different algae substrates using IBM SPSS Statistics software (Release ver. 18.0.0; SPSS Inc.).

\section{Results and Discussion}

\section{Kinetics of Nutrient Releasing from Decomposed BGA Biomasses}

Determining the kinetics of nutrient releasing from algae biomasses is a way to apprehend their digestion potential. As shown in Fig. 2, this indicated a fast nutrient excretion calculated by TDP and TDN from decomposed cyanobacteria. More than half phosphorus $(\mathrm{P})$ and nitrogen (N) were dissolved in one day (usually12 hours) of different algal amounts $(5,10,15$, and $20 \mathrm{~g} / \mathrm{L})$. Noticeably, the amount of TDN was progressively evolved due to the conversion of nitrogenous substances, e.g., protein.

Being alternative substrates, algae concentrates with intact cell walls require pretreatment (either by ultrasonic disruption, enzymatic hydrolysis, and/or thermal decomposition), especially for the concentrate like Chlorella vulgaris that has a rigid cell wall $[5,26]$. The dehydration procedure damages the cell wall of the BGA. This step makes the organic matters more accessible to the anaerobic microflora and thus were more easily being degraded. The success of $R$. palustris selection from algae biomasses was the bioavailability to organic and inorganic materials from the cellular inclusions apart from light conditions.

\section{Nutrient Comparison between Algae Substrate and ATYP Medium}

The incubation system of algae substrates automatically converted to anoxia within 12 to 20 hours either with or without $R$. palustris inoculants (data not shown). In the present work, overall nutrients (also the dissolved parts at the initiation time) of algae substrates $(3.33 \mathrm{~g} / \mathrm{L})$ and ATYP medium were compared. Shown in Fig. 3, the comparison indicated relative abundances of $\mathrm{N}$ and $\mathrm{C}$ contents in algae substrates. The initial $\mathrm{NH}_{4}-\mathrm{N}$ and TDN in algae substrates (released within two hours) were less, whereas they were progressively increased due to phototrophic activity from nitrogenous substance conversions (see results of $\mathrm{NH}_{4}-\mathrm{N}$ and TDN in Figs 4a-b). Noticeably, the amount of phosphorus of algae substrates was relatively low. We performed experiments to find out whether phosphorus was the limiting factor in the growth of PUF1. A final P-concentration of $100 \mathrm{mg} / \mathrm{L}$ was adjusted using phosphate with BGA concentration of $3.33 \mathrm{~g} / \mathrm{L}$, but no enhanced biomass production in stationary phase growth. Concomitantly, phosphorus reduced in the digestion did not differ much (data not shown). Cyanobacteria contain a vast amount of organic molecules, such as low-molecular- 


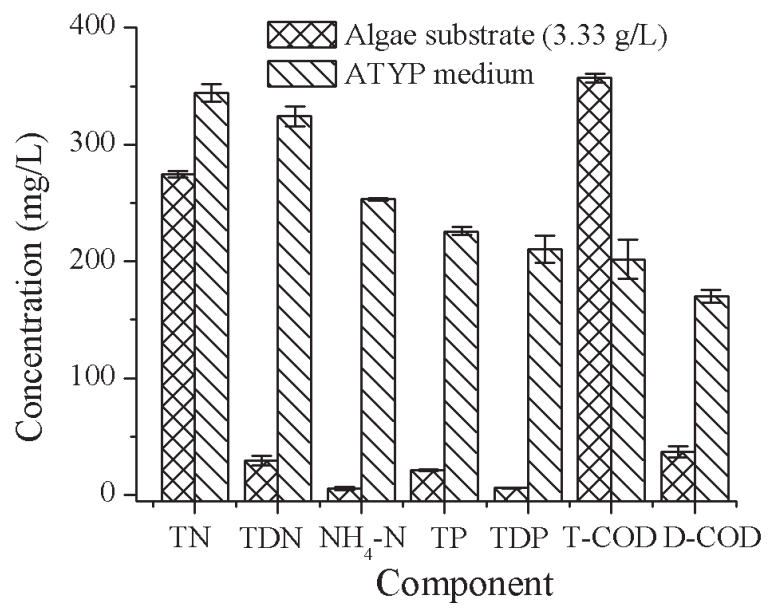

Fig. 3. Nutrient comparison between algae substrate (3.33 g/L) and ATYP medium. Values are means of three replications \pm standard deviation. Concentrations of $\mathrm{NH}_{4}-\mathrm{N}, \mathrm{TDN}, \mathrm{TDP}$, and $\mathrm{D}-\mathrm{COD}$ were the initial amounts released in two hours of algae substrates.

weight compounds and extrapolymeric substances composed of proteins, lipids, and nucleic acids, as well as acetate, propionate, lactate, and ethanol as fermentation products [14]. All of these molecules were beneficial in developing the growth substrate. For direct evidence, see Table 1 on the elemental analysis of algae biomasses (used for experiments), algal residuals (recollected after digestion), and $R$. palustris (in algae substrates).
Table 1. Main characteristics of algae biomass, algal residual, and $R$. palustri

\begin{tabular}{|c|c|c|c|}
\hline Element content & $\begin{array}{c}\text { Algae } \\
\text { biomass }\end{array}$ & $\begin{array}{c}\text { Algal } \\
\text { residual* }\end{array}$ & R. palustris \\
\hline $\mathrm{N}(\%)$ & 8.25 & 4.84 & 10.15 \\
\hline $\mathrm{C}(\%)$ & 42.96 & 43.71 & 51.46 \\
\hline $\mathrm{P}(\mathrm{mg} / \mathrm{g})$ & 6.40 & 3.64 & 15.08 \\
\hline $\mathrm{K}(\mathrm{mg} / \mathrm{g})$ & 5.99 & 0.50 & 1.36 \\
\hline $\mathrm{Ca}(\mathrm{mg} / \mathrm{g})$ & 10.48 & 16.07 & 2.52 \\
\hline $\mathrm{Mg}(\mathrm{mg} / \mathrm{g})$ & 2.68 & 1.73 & 2.39 \\
\hline $\mathrm{Fe}(\mathrm{mg} / \mathrm{g})$ & 0.83 & 1.16 & 0.40 \\
\hline $\mathrm{Zn}(\mu \mathrm{g} / \mathrm{g})$ & 28.75 & 36.99 & 37.71 \\
\hline $\mathrm{Ash}(\%)$ & 6.71 & 7.21 & 5.90 \\
\hline
\end{tabular}

*Algae biomasses after digestion were algal residuals. $R$. palustris cells loosely attached to the algal residuals were removed by dilutions with distilled water until there was no obvious red color found. The retrieval rate of algal residuals was $44.84 \%$ (mean of six replicates).

Therefore, the decomposed cyanobacteria can be potential supplements for $R$. palustris generation. Hiraishi et al. (1989) explained that organic nutrient strength affected the content of PNSB and the metabolic activity of photosynthetic sludge for wastewater treatment [27].
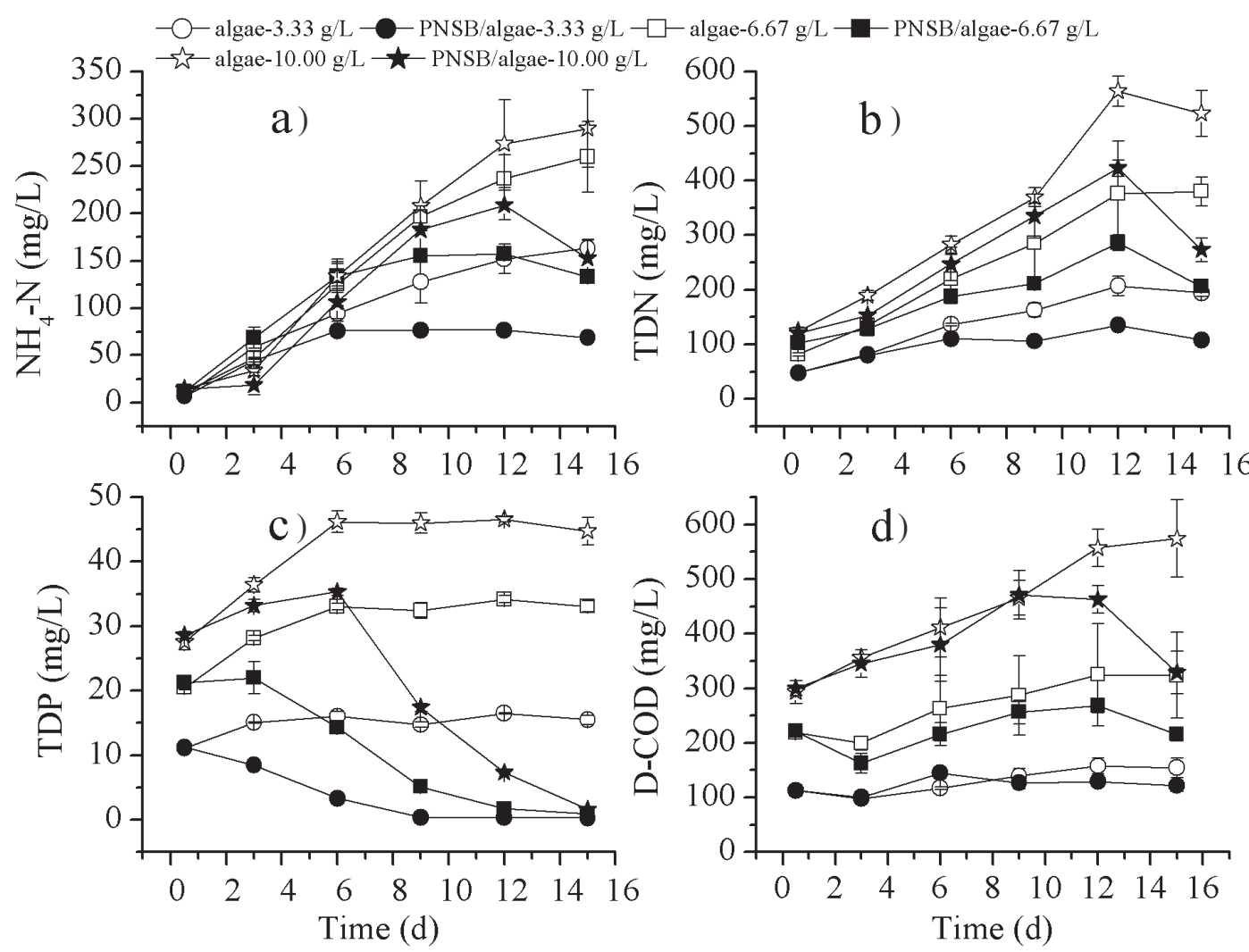

Fig. 4. Time course of $\mathrm{NH}_{4}-\mathrm{N} \mathrm{a}$ ), TDN b), TDP c), and D-COD d) of different algae substrates. Values are means of three replications \pm standard deviation. PNSB, namely $R$. palustris strain PUF1. 

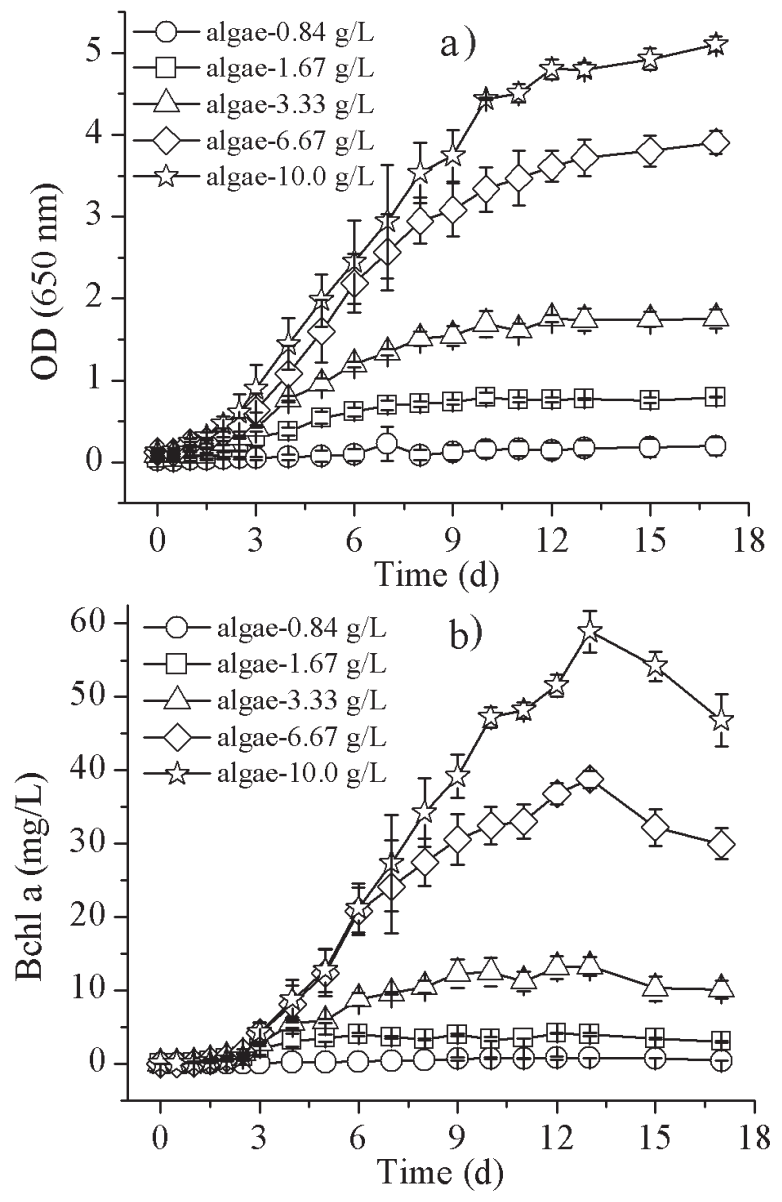

Fig. 5. Trends of $\mathrm{OD}_{650 \mathrm{~nm}}$ a) and Bchl a b) versus time attained under different algae substrates. Values are means of three replications \pm standard deviation. $\mathrm{OD}_{650 \mathrm{~nm}}$ was the corrected value that subtracted the absorbance from algae substrate. A dilution factor of five (one part cultures with four parts distilled water) was applied when in high density.

It observed a gradual inhibition of anaerobic ammonium oxidation activity by the high-strength organic matter, also an accumulated nitrite when the influent concentration of COD was 2,000 $\mathrm{mg} / \mathrm{L}$ [28]. We speculate that the amount of algae biomasses added would affect bacterial performance, which is an essential topic to determine a rational range for growing $R$. palustris in algae substrates. Meanwhile, factors involving biomass output and waste removal efficiency were to be calculated.

\section{Growth Performance of $R$. palustris with Different Algae Substrates}

Growth performances of $R$. palustris under different algae substrates varying from 0 to $10 \mathrm{~g} / \mathrm{L}$ were compared (Fig. 5). None of (or little) growth of strain PUF1 was observed in algae substrates of $0.84 \mathrm{~g} / \mathrm{L}$, while algae substrates $(10 \mathrm{~g} / \mathrm{L})$ gave a maximal Bchl a concentration of $\sim 59 \mathrm{mg} / \mathrm{L}, 3.69$ folds of $16 \mathrm{mg} / \mathrm{L}$ in ATYP medium (Table 2). Vigorous degradation was undergone in the log phase between $72 \mathrm{~h}$ to $216 \mathrm{~h}$ of algae substrates 3.33 to $10 \mathrm{~g} / \mathrm{L}$. Both OD650 $\mathrm{nm}$ and Bchl a content in
Table 2. Basic growth information based on logistical kinetic model and biomass growth between ATYP medium and different field algae substrates.

\begin{tabular}{|c|c|c|c|c|c|}
\hline Substrates & $\begin{array}{c}x c \\
(\mathrm{~h})^{*}\end{array}$ & $k\left(\mathrm{~h}^{-1}\right)$ & $\mathrm{OD}_{\max }$ & $\begin{array}{c}\mathrm{DW}^{*} \\
(\mathrm{~g} / \mathrm{L})\end{array}$ & $\begin{array}{c}\mathrm{Bchl} \mathrm{a} \\
(\mathrm{mg} / \mathrm{L})\end{array}$ \\
\hline ATYP medium & 59 & 0.059 & 1.8 & 0.91 & 16 \\
\hline Algae-1.67 g/L & 124 & 0.030 & 0.8 & 0.40 & 4 \\
\hline Algae-3.33 g/L & 136 & 0.028 & 1.7 & 0.86 & 12 \\
\hline Algae-6.67 g/L & 157 & 0.026 & 3.8 & 1.92 & 38 \\
\hline Algae-10.0 g/L & 177 & 0.025 & 4.9 & 2.47 & 58.92 \\
\hline
\end{tabular}

*The dry weight (DW) of $R$. palustris strain PUF1 was calculated by the following empirical formula: $y(\mathrm{OD} 650 \mathrm{~nm})=1.9768 x+0.002(x: \mathrm{DW}(\mathrm{g} / \mathrm{L}), \mathrm{N}=23$, $\left.R^{2}=0.95\right) .50 \mathrm{~mL}$ bacterial cultures were filtrated through a $47 \mathrm{~mm} \mathrm{GF} / \mathrm{F}$ glass microfiber filter (pore size $\sim 0.7 \mu \mathrm{m}$, Whatman, CAT No. 1828-047, GE Healthcare Life Sciences, Bucks, UK) and the filter was dried to a constant weight at $105^{\circ} \mathrm{C}$ for $12 \mathrm{~h}$. The DW was determined by weighing the filters.

the stationary phase were positively correlated $\left(R^{2}>0.98\right)$ with the algae concentrations (from 0.84 to $10 \mathrm{~g} / \mathrm{L}$ ). The range of specific growth rate $\left(\mathrm{k}, \mathrm{h}^{-1}\right)$ of $R$. palustris from algae substrates was 0.025-0.030 (see Table 2), which was $42.4-50.8 \%$ of experiments performed using ATYP medium. A report showed a growth rate of $0.021 \mathrm{~h}^{-1}$ of $R$. palustris $42 \mathrm{OL}$ cells grown in an outdoors $50 \mathrm{~L}$ photobioreactor containing RPP medium, and a longer lag phase of $46 \mathrm{~h}$ existed after inoculation [29]. The specific growth rates of five high-hydrogen producers of anoxygenic photosynthetic bacteria were variable, that they were $0.0269 \mathrm{~h}^{-1}$ to $0.0475 \mathrm{~h}^{-1}$ under anaerobic-low light conditions $(3,000 \mathrm{lux})$ at $30^{\circ} \mathrm{C}[30]$.

As shown in Fig. 5b), Bchl a concentration, in batch experiments of algae substrates $3.33 \mathrm{~g} / \mathrm{L}$, first approached its peak value (usually in seven days). Afterward, it was significantly reduced. In early cultivation, biosynthesis of Bchl a was temporarily depressed in algae substrates of $10 \mathrm{~g} / \mathrm{L}$ compared to algae substrates of $6.67 \mathrm{~g} / \mathrm{L}$. This inhibitive effect diminished seven days later and was followed by a steep rise of Bchl a in the following days. Results showed an important effect of organic loading rate on enzyme activity [31], suggesting that strength from the ions and organic nutrients regulated the photosynthesis of photosynthetic microorganisms [9, 32]. The increasing non-soluble particles and soluble pigments were another potential factors affecting growth performances by changing the refractive indexes of algae substrates, since smaller particles, regardless of shape, generally inhibited light penetration into the reactor more than larger particles [33].

\section{Nutrient Utilization}

Anaerobic digestion of algae biomasses caused large shifts in nutrient levels. As shown in Table 1, N contents of algal materials before and after digestion were 8.25 
Table 3. Removal rates of $\mathrm{NH}_{4}-\mathrm{N}$, TDN, TDP, and COD in the digestate by $R$. palustris strain PUF1 in a 15-day experiment.

\begin{tabular}{|c|c|c|c|c|}
\hline \multirow{2}{*}{ Algae substrate } & \multicolumn{4}{|c|}{ Removal rate (\%) } \\
\cline { 2 - 5 } & $\mathrm{NH}_{4}-\mathrm{N}(\%)$ & TDN (\%) & TDP (\%) & D-COD (\%) \\
\hline $3.33 \mathrm{~g} / \mathrm{L}$ & $58.15 \pm 1.67$ & $43.89 \pm 0.24$ & $98.07 \pm 0.40$ & $30.78 \pm 2.04$ \\
\hline $6.67 \mathrm{~g} / \mathrm{L}$ & $48.35 \pm 9.3$ & $44.92 \pm 0.92$ & $97.08 \pm 0.57$ & $36.42 \pm 1.65$ \\
\hline $10.0 \mathrm{~g} / \mathrm{L}$ & $47.05 \pm 6.61$ & $47.74 \pm 0.58$ & $96.23 \pm 0.64$ & $38.71 \pm 9.04$ \\
\hline
\end{tabular}

$( \pm 0.08) \%$ and $4.84( \pm 0.02) \%$, while they were 6.41 $( \pm 0.18)$ and $3.64( \pm 0.13) \mathrm{mg} / \mathrm{g}$ for $\mathrm{P}$ calculation. Based on a retrieval rate of $44.84 \%, \mathrm{~N}$ and $\mathrm{P}$ released from algae biomasses were $74.54 \%$ and $73.69 \%$. In the digestate, $\mathrm{NH}_{4}-\mathrm{N}$ was the major nitrogen comprising TDN by the onset of log phase growth (Figs 4a-b). As shown in Fig. 4d), of the first nine-day incubation, D-COD levels in controls (without $R$. palustris inoculants) were comparable to treatments having $R$. palustris added. This indicated a balanced degradation and consumption of lower fatty acids on these days. Rapid uptake of volatile fatty acids by PNSB was reported [34]. Results demonstrated that total COD actually increased during the batch experiments due to phototrophic activity with increasing soluble COD consumption in batch experiments on settled wastewater [18].

Longer-term $\mathrm{NH}_{4}-\mathrm{N}$ removal is directly linked to soluble COD assimilation [18]. In the present study, both D-COD and $\mathrm{NH}_{4}-\mathrm{N}$ from operations were linearly correlated with $\mathrm{OD}_{650 \mathrm{~nm}}$ from strain PUF1, especially $\mathrm{NH}_{4}-\mathrm{N}\left(R^{2}=0.79, \mathrm{~N}=18\right)$. Results indicated that cell assimilation contributed to the longer-term reduction of soluble COD, nitrogen, and phosphorous in the digestates. As shown in Table 3, the removal efficiencies of $\mathrm{NH}_{4}-\mathrm{N}$, TDN, TDP, and D-COD in the digestates on average were $58.15 \%, 43.89 \%, 98.07 \%$, and $30.78 \%$ of algae substrates $3.33 \mathrm{~g} / \mathrm{L}$. Importantly, no marked difference of the removal efficiencies was found within the batch experiments of algae substrates $3.33,6.67$, and $10 \mathrm{~g} / \mathrm{L}$.

Noticeably, the increase of $\mathrm{NH}_{4}-\mathrm{N}$ in controls indicates the existence of indigenous bacteria brought by algae biomasses, while it is reasonable to suppose the nutritional difference of controls and treatments in algae substrates to the assimilation of strain PUF1. The amounts of $\mathrm{N}$ and $\mathrm{P}$ acquired by strain PUF1 were $94.40( \pm 3.55)$ and $15.65( \pm 0.06) \mathrm{mg} / \mathrm{L}$ (see the reductions of TDN and TDP shown in Figs. 4b-c, whereas they were 88.31 and $13.08 \mathrm{mg} / \mathrm{L}$ on average based on the elemental results of $R$. palustris from Table 1). This case supports the idea that photo-heterotrophs using light energy gain an advantage over strict heterotrophs [35]. Reports show that versatility and flexibility with respect to the utilization of lower fatty acids provide Rhodopseudomonas species with a competitive advantage over Rhodobacter species [36-37]. Being attached to particles gives aerobic anoxygenic photosynthetic (AAP) bacteria an enhanced ability to synthesize Bchl a [35].
Though low in carbon to nitrogen $(\mathrm{C} / \mathrm{N})$ ratio of microalgae [26], it seems not to be a defect in single-stage biomass production of $R$. palustris cells provided with a rational loading rate. Regarding the bacterial growth and subsequent costs from wastewater retreatment and power supply, algae concentration of 1.67 to $10 \mathrm{~g} / \mathrm{L}$ is viable, whereas algae biomasses of 3.33 to $6.67 \mathrm{~g} / \mathrm{L}$ is advisable. Bioaugmentation using selected strains or mixed cultures in wastewater treatments benefit catabolizing specific compounds, e.g., refractory organics, or overall COD enhancing removal efficiency (for details see [38]). PNSB, an eco-friendly and cheap tool for bioremediation, has high efficiency in wastewater treatment in the reduction of $\mathrm{N}, \mathrm{P}$, and COD [39]. By 1:4 dilutions, reduction of 50\% in COD was observed by applying Rhodobacter sphaeroides Z08 during pharmaceutical wastewater treatment with biomass yield of $780 \mathrm{mg} / \mathrm{L}$ and specific growth of $0.015 \mathrm{~h}^{-1}[40]$.

\section{Total Lipid, PHB, and Fatty Acid Production in $R$. palustris}

In the present study, total lipid, PHB, and fatty acids of strain PUF1 were determined for algae substrates and ATYP medium. Total lipid and PHB attained in R. palustris with algae substrates $(3.33 \mathrm{~g} / \mathrm{L})$ were $37.68( \pm 1.17) \%$ and 11.67 $( \pm 1.30) \%$. And they were comparable to the value of 37.86 $( \pm 0.97) \%$ and $13.64( \pm 2.26) \%$ observed in ATYP medium. Total lipid content of the dry biomasses of $R$. palustris PUF1 fell into the range $36-39 \%$ of the literature using the same species when the irradiance was within the 56-151 $\mathrm{W} \mathrm{m}^{-2}$ range [41]. Results indicated a higher PHB production rate of $8.4 \%$ on butyrate of $28 \mathrm{mM}$ $(2.47 \mathrm{~g} / \mathrm{L})$ than that of $5.3 \%$ on acetate of $39 \mathrm{Mm}$ (2.34 g/L) in R. palustris WP3-5 [10]. The type of nitrogen source does not cause any marked variation in the intracellular concentration of PHB [42]. R. palustris strain PUF1 contained large amounts of saturated, unsaturated, and cyclo fatty acids. Results showed that fatty acids of 18:1w7c and 16:00 of strain PUF1 grown on algae substrates $(3.33 \mathrm{~g} / \mathrm{L})$ accounted for up to $60.14 \%$ and $13.66 \%$, and were comparable to a pure culture with ATYP medium, in which $18: 1 \mathrm{w} 7 \mathrm{c}$ was $58.74 \%$ and $16: 00$ was $9.36 \%$. These results indicate that algae biomasses are a potent feedstock for the biomass generation of $R$. palustris, thereby providing a new direction on the management of harmful algae. 


\section{Conclusions}

Field BGA biomass has proven to be an ideal substrate for culturing $R$. palustris. Nutrients from decomposed algae biomasses were biologically concentrated through growth. More than $40 \%$ of nitrogen in the digestate was removed while it was $95 \%$ or more for the phosphorus in longer-term (15 days) experiments with algae biomasses ranging from 3.33 to $10 \mathrm{~g} / \mathrm{L}$.

Our work demonstrated that practically applying $R$. palustris for nutrient recovery from field BGA biomasses is promising. It achieves great ecological and economic benefits since the added products from $R$. palustris. For further investigation, more attention should be given to the ammonia toxicity due to the low $\mathrm{C} / \mathrm{N}$ ratio of algae, and a mutualistic microbial community will make sense for advanced nutrient utilization and wastewater treatment.

\section{Acknowledgements}

This work was supported by the National Natural Science Foundation of China (grant Nos. 31370504 and 31270509) and the Joint NSFC-ISF Research Program, and was jointly funded by the National Natural Science Foundation of China and the Israel Science Foundation (grant No. 41561144008), and the Major Science and Technology Program for Water Pollution Control and Treatment of China (grant No. 2013ZX07102005).

\section{References}

1. WATSON S.B., MOLOT L. Encyclopedia of Aquatic Ecotoxicology: Harmful Algal Blooms. Springer Netherlands, 619 (2), 575, 2015.

2. YANG F., ZHOU Y., YIN L., ZHU G., LIANG G., PU Y. Microcystin-degrading activity of an indigenous bacterial strain Stenotrophomonas acidaminiphila MC-LTH2 isolated from Lake Taihu. PLoS One, 9 (1), e86216, 2014.

3. DUAN H., MA R., XU X., KONG F., ZHANG S., KONG W., HAO J., SHANG L. Two-decade reconstruction of algal blooms in China's Lake Taihu. Environ. Sci. Technol. 43 (10), 3522, 2009.

4. CHEN W., JIA Y., LI E., ZHAO S., ZHOU Q., LIU L., SONG L. Soil-based treatments of mechanically collected cyanobacterial blooms from Lake Taihu: efficiencies and potential risks. Environ. Sci. Technol. 46 (24), 13370, 2012.

5. SIALVE B., BERNET N., BERNARD O. Anaerobic digestion of microalgae as a necessary step to make microalgal biodiesel sustainable. Biotechnol. Adv. 27 (4), 409, 2009.

6. CARDOZO K.H., GUARATINI T., BARROS M.P., FALCÃO V.R., TONON A.P., LOPES N.P., CAMPOS S., TORRES M.A., SOUZA A.O., COLEPICOLO P. Metabolites from algae with economical impact. Comp. Biochem. Phys. C. 146 (1), 60, 2007.

7. KHUSNUTDINOVA A.N., OVCHENKOVA E.P., KHRISTOVA A.P., LAURINAVICHENE T.V., SHASTIK E.S., LIU J., TSYGANKOV A.A. New tolerant strains of purple nonsulfur bacteria for hydrogen production in a two-stage integrated system. Int. J. Hydrogen Energ. 37 (10), 8820, 2012.

8. MUKKATAK.,KANTACHOTED.,WITTAYAWEERASAK B., TECHKARNJANARUK S., BOONAPATCHAROEN N. Diversity of purple nonsulfur bacteria in shrimp ponds with varying mercury levels. Saudi J. Biol. Sci. 2015.

9. LARIMER F.W., CHAIN P., HAUSER L., LAMERDIN J., MALFATTI S., DO L., LAND M.L., PELLETIER D.A., BEATTY J.T., LANG A.S., TABITA F.R., GIBSON J.L., HANSON T.E., BOBST C., TORRES J.L., PERES C., HARRISON F.H., GIBSON J., HARWOOD C.S. Complete genome sequence of the metabolically versatile photosynthetic bacterium Rhodopseudomonas palustris. Nat. Biotechnol. 22 (1), 55, 2004.

10. CHEN Y.T., WU S.C., LEE C.M. Relationship between cell growth, hydrogen production and poly- $\beta$-hydroxybutyrate (PHB) accumulation by Rhodopseudomonas palustris WP3-5. Int. J. Hydrogen Energ. 37 (18), 13887, 2012.

11. PUYOL D., LU K., HUELSEN T., BARRY E., YUAN Z., BATSTONE D. Poly-phosphate accumulation by purple phototrophic bacteria for total phosphorus reclaim from domestic wastewater. $1^{\text {st }}$ IWA Resource Recovery Conference. 2015.

12. SAKPIROM J., KANTACHOTE D., NUNKAEW T., KHAN E. Characterizations of purple non-sulfur bacteria isolated from paddy fields, and identification of strains with potential for plant growth-promotion, greenhouse gas mitigation and heavy metal bioremediation. Res. Microbiol. 2016.

13. WU T.Y., HAY J.X.W., KONG L.B., JUAN J.C., JAHIM J.M. Recent advances in reuse of waste material as substrate to produce biohydrogen by purple non-sulfur (PNS) bacteria. Renew. Sust. Energ. Rev. 16 (5), 3117, 2012.

14. SUBASHCHANDRABOSE S.R., RAMAKRISHNAN B., MEGHARAJ M., VENKATESWARLU K., NAIDU R. Consortia of cyanobacteria/microalgae and bacteria: biotechnological potential. Biotechnol. Adv. 29 (6), 896, 2011.

15. KAWAGUCHI H., HASHIMOTO K., HIRATA K., MIYAMOTO $\mathrm{K} . \mathrm{H}_{2}$ production from algal biomass by a mixed culture of Rhodobium marinum A-501 and Lactobacillus amylovorus. J. Biosci. Bioeng. 91 (3), 277, 2001.

16. KIM M., BAEK J., YUN Y., JUNSIM S., PARK S., KIM S. Hydrogen production from Chlamydomonas reinhardtii biomass using a two-step conversion process: Anaerobic conversion and photosynthetic fermentation. Int. J. Hydrogen Energ. 31 (6), 812, 2006.

17. CARVER S.M., HULATT C.J., THOMAS D.N., TUOVINEN O.H. Thermophilic, anaerobic co-digestion of microalgal biomass and cellulose for $\mathrm{H}_{2}$ production. Biodegradation 22 (4), 805, 2011.

18. HULSEN T., BATSTONE D.J., KELLER J. Phototrophic bacteria for nutrient recovery from domestic wastewater. Water Res. 50, 18, 2014.

19. KONG Q., ZHAI C., GUAN B., LI C., SHAN S., YU J. Mathematic modeling for optimum conditions on aflatoxin $\mathrm{B}_{1}$ degradation by the aerobic bacterium Rhodococcus erythropolis. Toxins (Basel), 4 (11), 1181, 2012.

20. MEKJINDA N., RITCHIE R.J. Breakdown of food waste by anaerobic fermentation and non-oxygen producing photosynthesis using a photosynthetic bacterium. Waste Manag. 35, 199, 2015.

21. RITCHIE R.J., RUNCIE J.W. Photosynthetic electron transport in an anoxygenic photosynthetic bacterium Afifella (Rhodopseudomonas) marina measured using PAM fluorometry. Photochem. Photobiol. 89 (2), 370, 2013. 
22. PUSHPARAJ B., BUCCIONI A., PAPERI R., PICCARDI R., ENA A., CARLOZZI P., SILI C. Fatty acid composition of Antarctic cyanobacteria. Phycologia 47, 430, 2008.

23. BORMANN E.J., LEISSNER M., BEER B. Growth and formation of poly (hydroxybutyric acid) by Methylobacterium rhodesianum at methanol concentrations of above $25 \mathrm{~g} / \mathrm{l}$. Eng. Life Sci. 17 (4), 279, 1997.

24. BUCCIONI A., ANTONGIOVANNI M., PETACCHI F., MELE M., SERRA A., SECCHIARI P., BENVENUTI D. Effect of dietary fat quality on C18:1 fatty acids and conjugated linoleic acid production: An in vitro rumen fermentation study. Anim. Feed Sci. Tech. 127 (3-4), 268, 2006.

25. APHA. Standard Methods for the Examination of Water and Wastewater, $20^{\text {th }}$ ed. Washington DC, 1998.

26. WARD A.J., LEWIS D.M., GREEN F.B. Anaerobic digestion of algae biomass: A review. Algal Res. 5, 204, 2014.

27. HIRAISHI A., SHI J.L., KITAMURA H. Effects of organic nutrient strength on the purple nonsulfur bacterial content and metabolic activity of photosynthetic sludge for wastewater treatment. J. Ferment. Bioeng. 68 (4), 269, 1989.

28. ZHANG J., HAN Y., ZHOU J., ZHANG X., CHEN L. Effect of organic matter strength on single-stage nitrogen removal using anammox and partial nitritation (SNAP) for treatment of high strength ammonia wastewater. J. Chem.Pharm. Res. $6(10), 307,2014$.

29. ADESSI A., TORZILLO G., BACCETTI E., DE PHILIPPIS $\mathrm{R}$. Sustained outdoor $\mathrm{H}_{2}$ production with Rhodopseudomonas palustris cultures in a $50 \mathrm{~L}$ tubular photobioreactor. Int. J. Hydrogen Energ. 37 (10), 8840, 2012.

30. SUWANSAARD M., CHOORIT W., ZEILSTRARYALLS J.H., PRASERTSAN P. Isolation of anoxygenic photosynthetic bacteria from Songkhla Lake for use in a two-staged biohydrogen production process from palm oil mill effluent. Int. J. Hydrogen Energ. 34 (17), 7523, 2009.

31. VENKATAKRISHNAN H., TAN Y., MAJID M.B.A., PATHAK S., SENDJAJAA.Y., LI D., LIU J.J.L., YANZ., NG W.J. Effect of a high strength chemical industry wastewater on microbial community dynamics and mesophilic methane generation. J. Environ. Sci. 26 (4), 875, 2014.

32. TANG J.K., SAIKIN S.K., PINGALI S.V., ENRIQUEZ M.M., HUH J., FRANK H.A., URBAN V.S., ASPURU-
GUZIK A. Temperature and carbon assimilation regulate the chlorosome biogenesis in green sulfur bacteria. Biophys. J. 105 (6), 1346, 2013.

33. HANNIS K.G. Optical behavior of algae particles in photobioreactors. Thesis, 2013.

34. KIM M.K., CHOI K.M., YIN C.R., LEE K.Y., IM W.T., LIM J.H., LEE S.T. Odorous swine wastewater treatment by purple non-sulfur bacteria, Rhodopseudomonas palustris, isolated from eutrophicated ponds. Biotechnol. Lett. 26 (10), 819, 2004.

35. COTTRELL M.T., RAS J., KIRCHMAN D.L. Bacteriochlorophyll and community structure of aerobic anoxygenic phototrophic bacteria in a particle-rich estuary. ISME J. 4 (7), 945, 2010.

36. OKUBO Y., FUTAMATA H., HIRAISHI A. Characterization of phototrophic purple nonsulfur bacteria forming colored microbial mats in a swine wastewater ditch. Appl. Environ. Microbiol. 72 (9), 6225, 2006.

37. OKUBO Y., FUTAMATA H., HIRAISHI A. Distribution and capacity for utilization of lower fatty acids of phototrophic purple nonsulfur bacteria in wastewater environments. Microbes Environ. 20 (3), 135, 2005.

38. HERRERO M., STUCKEY D.C. Bioaugmentation and its application in wastewater treatment: A review. Chemosphere 140, 119, 2015.

39. IDI A., NOR M.H.M., WAHAB M.F.A., IBRAHIM Z. Photosynthetic bacteria: an eco-friendly and cheap tool for bioremediation. Rev. Environ Sci. Bio. 14 (2), 271, 2015.

40. MADUKASI E.I., CHUNHUA H., ZHANG G. Isolation and application of a wild strain photosynthetic bacterium to environmental waste management. Int. J. Environ. Sci. Te. 8 (3), 513, 2011.

41. CARLOZZI P., PINTUCCI C., PICCARDI R., BUCCIONI A., MINIERI S., LAMBARDI M. Green energy from Rhodopseudomonas palustris grown at low to high irradiance values, under fed-batch operational conditions. Biotechnol. Lett. 32 (4), 477, 2009.

42. PHILIPPIS R.D., ENA A., GUASTINI M., SILI C., VINCENZINI M. Factors affecting poly- $\beta$-hydroxybutyrate accumulation in cyanobacteria and in purple non-sulfur bacteria. FEMS Microbiol. Lett. 103 (2-4), 187, 2010. 